\title{
OPINI MAHASISWA MENGENAI ISU PEMINDAHAN LOKASI PELAKSANAAN HUKUM CAMBUK KE PENJARA (Studi Kasus Pada Mahasiswa Prodi Hukum FISIP UTU)
}

\author{
Rena Juliana \\ Program Studi Seni Teater, Jurusan Seni Pertunjukan, \\ Institut Seni Budaya Indonesia Aceh \\ Email: renajuliana@isbiaceh.ac.id
}

\begin{abstract}
This research aims to analyze how students of Law Major of Social and Political Sciences Faculty of Teuku Umar University responded to the issue of transferring the location of the execution of the caning to prison. Spiral of silence theory is the underlying theory of this research. The method used in this research is quantitative descriptive method by distributing questionnaires to 20 students. From the results of the research found that the students did not agree with the government plan to move the location of the execution of the caning to prison. It is considered that such a punishment will not make the defendants deterrent because the effect of shame does not exist. The defendant will not be punished by the public for not being shown publicly. The students also considered that the prohibition to take pictures and recordings when the process of application of caning law should not be prohibited. In addition the students considered that the implementation of caning law in the mosque will not cause a sense of the phobia of investors to instill their shares in Aceh and the implementation of caning law in the mosque does not violate human rights. The students alleged the transfer of location of the canning law full of political interests so it is feared that the ruling parties in violation of the Shariah will not receive the caning punishment because of their power.
\end{abstract}

Keyword: Opinion, students of Law Major, Caning

\section{PENDAHULUAN}

Provinsi Aceh merupakan satu-satunya provinsi di Indonesia yang menerapkan syariat Islam. Pada hakikatnya penerapan syariat Islam ini sudah menjadi impian masyarakat Aceh sejak dahulu. Syariatlislam yang belandaskan agama Islam telah diperjuangakan terus menerus oleh masyarakat dan para pemimpin Aceh. Berbagai cara telah ditempuh guna dilegalkannya penerapan syariat Islam ini. Penerapan syariat Islam yang tekah melalui berbagai proses akhirnya bisa terealisasikan juga. Pada saat penandatangana perjanjian MoU Helsinki, penerapan syariat Islam di wilayah Aceh merupakan salah satu yang menjadi syarat ditandatanginya Mou tersebut. Di dalam Nota Kesepahaman antara Pemerintahan Republik Indonesia dan Gerakan Aceh Merdeka menjelaskan bahwa Qanun Aceh akan disusun kembali untuk Aceh dengan menghormati tradisi sejarah dan adat istiadat masyarakat Aceh yang akan mencerminkan kebutuhan hukum terkini Aceh. Nota Kesepahaman tersebut yang menegaskan bahwa Aceh berhak menyusun peraturannya sendiri mengenai bagaimana syariat Islam dijalankan di Aceh berdasarkan kondisi masyarakat Aceh saat ini.

Penerapan syariat Islam sendiri bukan tidak mendapat kendala. Penerapannya bahkan menghadirkan berbagai pendapat. Masih ada masyarakat yang pro terhadap penerapan syariat Islam dan ada juga yang kontra walaupun penerapan Syari'at Islam di Aceh telah berlangsung selama beberapa tahun. Hal ini dikarenakan tidak semua masyarakat dan elemen-elemen di dalam masyarakat menyetujui segala kebijakan yang pemerintah terapkan. Terlebih lagi dengan 
hukuman yang didera terdakwa pelanggar syari'ah seperti hokum cambuk.

Hukuman cambuk masih menjadi perdebatan diberbagai kalangan. Mulai dari kalangan masyarakat, organisasi-organisasi masyarakat, LSM bahkan penetangan hukum cambuk yang terapkan di Aceh banyak diprotes oleh pihak luar negeri. Hukum cambuk masih dianggap bentuk pelanggaran HAM oleh sebagian kalangan. Hal ini terlihat bagaimana LSM pembela HAM melakukan berbagai aksi penolakan terhadap hukuman ini. Mereka yang kurang setuju dengan ditetapkannya hukum cambuk sebagai sebuah hukuman syari'ah berpandangan bahwa hukuman cambuk dinilai tidak mengedepankan HAM, pelaksanaannya jauh dari nilai kemanusiaan, tidak manusiawi dan menurunkan harkat dan martabat manusia.

Belakangan ini ada wacana pemerintah untuk mengubah lokasi pelaksanaan hukuman cambuk bagi para pelanggar syariah. Perihal pelaksanaan hukum cambuk yang biasanya dilakukan di lapangan masjid dan dapat ditonton oleh masyarakat akan dipindahkan ke penjara sehingga masyarakat tidak lagi bisa menyaksikan bagaimana pelaksanaan hukam tersebut, dimana para algojo yang ditunjuk akan mencambuk terpidana syariah tersebut di muka umum.

Dalam berbagai berita telah disiarkan informasi perihal pemindahan lokasi hukaman cambuk ini. Pada news.okezone.com menyebutkan bahwa Pemerintah Aceh akan melaksanakan eksekusi hukuman cambuk bagi para pelanggar syariat di dalam penjara, yang diatur dalam Peraturan Gubernur Aceh. Penerapan peraturan baru itu mengacu pada pelaksanaan Qanun Nomor 7 Tahun 2013 tentang Hukum Acara Jinayat dan Qanun Nomor 6 Tahun 2014 tentang Hukum Jinayat. Terkait dengan pelaksanaan kedua qanun tersebut, dan atas penerapan eksekusi cambuk yang berlangsung dalam penjara, Gubernur Aceh Irwandi Yusuf telah menandatangain kerjasama tersebut dengan Kepala Kantor Wilayah Kementerian Hukum dan HAM Aceh, Yuspahruddin yang disaksikan Menteri Hukum dan Hak Asasi Manusia, Yosanna Laoly di Amel Convention Hall, Banda Aceh (Surry, 2018). Irwandi Yusuf mengatakan, selama ini pelaksanaan hukuman cambuk dilakukan di depan umum, tepatnya di halaman masjid. Namun, kini pelaksanaan eksekusi cambuk itu akan berlangsung di dalam penjara, dengan alasan meredam protes yang timbul dari pihak luar Aceh. "Kita tidak mau pelaksanaan hukuman kita ini menganggu urusan luar negeri. Dan yang kita lakukan dengan melaksanakan hukuman di dalam penjara bisa disaksikan oleh masyarakat tergantung kapasitas penjara, wartawan, tetapi tidak bisa dilihat oleh anak kecil, atau warga yang ingin membawa HP (Handphone) untuk merekam," pungkas Irwandi (Surry, 2018).

Fenomena di atas merupakan konteks penelitian ini, sekaligus menjadi alasan mengapa penelitian ini harus dibuat. Sebagai agent of change, mahsiswa harus digali pendapatnya mengenai isu tersebut. Mahasiswa Prodi Ilmu Hukum UTU dipilih karena mereka adalah mahasiswa yang mempelajari ilmu hukum dan erat kaitannya dengan hukum. Oleh sebab itu penelitian ini berjudul "Opini Mahasiswa Mengenai Isu Pemindahan Lokasi Pelaksanaan Hukum Cambuk Ke Penjara (Studi Kasus Pada Mahasiswa Prodi Hukum FISIP UTU)”.

Berdasarkan latar belakang di atas, maka dapat disimpulkan yang menjadi alasan utama yang ingin dikaji dalam penelitian ini adalah bagaimana mahasiswa Prodi Ilmu Hukum FISIP UTU menanggapi perihal isu pemindahan lokasi pelaksanaan hukum cambuk ke penjara? Oleh sebab itu yang menjadi tujuan umum dari penelitian ini yaitu untuk menganalisis bagaimana mahasiswa Prodi Ilmu Hukum FISIP UTU menanggapi perihal isu pemindahan lokasi pelaksanaan hukum cambuk ke penjara. Metode yang digunakan dalam penelitian ini adalah metode deskriptif kuantitatif dengan menyebarkan kuisioner kepada 20 mahasiswa Prodi Ilmu Hukum FISIP UTU.

Penelitian ini diharapkan dapat memberikan kontribusi bagi pemerintah dalam menegakkan hukum yang sudah sepatutnya dipatuhi oleh seluruh masyarakat. Di samping itu, penelitian ini diharapkan dapat memberikan pemahaman kepada pembaca mengenai telah ditetapkan dan dijalankan sebuah hukum cambuk yang bertujuan bukan hanya untuk menghukum namun juga untuk membuat jera pelaku pelanggaran syariah tersebut. 


\section{TINJAUAN PUSTAKA Hukum Cambuk}

Syariat Islam dalam pelaksanaannya sebaiknya tidak melanggar hak-hak asasi manusia (HAM), hal ini diungkapkan oleh Alyasa' Abu Bakar (Yani, 2011: 181) yang menulis mengenai "Syariat Islam jangan Bertentangan dengan HAM". Dalam tulisannya, tidak ada pernyataan yang menyatakan adanya penentangan dengan pelaksanaan hukuman cambuk. Beliau menyatakan setuju dengan hukuman cambuk, menurutnya "Semua hukuman adalah derita, yang menurut filosof Eropa, penderitaan paling berat adalah kehilangan kemerdekaan. Logikanya karena hak asasi paling dasar adalah kebebasan, maka hukuman cambuk yang diterapkan adalah yang lebih ringan dan yang agak jauh dari pelanggaran HAM." Sejalan dengan apa yang diungkapkan oleh Alyasa' Abu Bakar,Prof. Syahrizal, (Bantasyam dan Siddiq, 2009: 140) menyatakan bahwa: "Terkait dengan urusan hak asasi manusia, penerapan hukum Islam di Aceh dipandang oleh sebagian kalangan di Aceh tidak melanggar HAM. Penerapan hukum Syari'at Islam bukan untuk menghukum orang, akan tetapi pada prinsipnya justru melindungi, menjaga keamanan dan ketertiban semua orang."

Pelaksanaan Syari'at Islam di Aceh pada dasarnya telah disesuaikan dengan hukumhukum yang berlaku di Indonesia dan juga hukuman yang ada dalam peraturan syariat Islam tidak melanggar HAM. Hal tersebut agar penerapan Syari'at Islam tidak bertentangan dengan Hukum-hukum lainnya yang ada di Indonesia (Yani, 2011:204). Yani (2011:204) juga menambahkan bahwa:

"Bukan hanya di Aceh, penerapan hukum Jinayat dalam Islam didukung konsep HAM yang telah disahkan dalam Deklarsi Universal Hak-hak Asasi Manusia Menurut Islam (DIUHR) 1981 dan Deklarasi Kairo (CDHRI) 1990-yang menyatakan bahwa penerapan syariat Islam di dunia dapat disesuaikan dengan penafsiran fiqh berbagai mazhab yang ada dalam Islam menurut kondisi dan situasi umat Islam berada, (tak terkecuali di Aceh-Indonesia). Menurut Hukum Islam dan konsep HAM Islam, menghukum orang yang bersalah bukan bertujuan untuk menyiksa mereka secara tidak manusiawi dan merendahkan martabatnya. Namun merupakan balasan atas kesalahan yang ia lakukan, di samping merupakan salah satu cara taubah (permohonan ampunan/penyesalan dari dosanya), bila dilakukan dengan suka rela. Tujuan Hukum Islam adalah untuk mencegah kriminalitas - (kesalahan) yang sama-dilakukan oleh umat Islam yang lain."

Singapura termasuk salah satu negara yang masih memberlakukan hukuman cambuk. Hukuman cambuk merupakan warisan dari koloni Inggris yang pernah menjajah Singapura. Selain Singapura, Malaysia juga merupakan Negara bekas jajahanI nggris yang masih memberlakukan hukuman cambuk. Di Singapura, hukuman cambuk biasanya dilakukan dengan rotan dan diterapkan pada pelanggaran pidana seperti narkoba, perampokan, pidana terkait seks, pembunuhan, kepemilikan senjata tidak sah, vandalisme, kerusuhan, peminjaman uang secara legal, dan untuk orang asing yang melewati batas tinggal di Singapura hingga 90 hari (untuk menghindari keberadaan pekerja imigran ilegal). Hukuman cambuk juga bisa dikombinasikan dengan hukuman lainnya secara bersamaan. Sergei Sekov misalnya, seorang pria berkewarganegaraan Ukraina pernah dihukum cambuk karena melakukan pelecehan seksual dengan menyentuk bokong salah seorang pramugari Singapore Airlines sebanyak dua kali. Walaupun hanya 2 kali, pria ini tetap dikenakan hukuman cambuk atas tuduhan melakukan pelecehan seksual. Selain dicambuk, ia juga diwajibkan membayar sejumlah denda. Menurut prosedur hukum yang berlaku di Singapura, hukuman cambuk hanya boleh dikenakan pada lakilaki berusia 18 sampai 50 tahun dan telah dinyatakan layak secara medis untuk menerima hukuman cambuk. Artinya laki-laki berusia di atas 50 tahun, wanita dan anak-anak di bawah 18 tahun tidak diperkenankan menerima hukuman cambuk oleh negara. Jumlah cambukan tergantung besarnya kesalahan, namun maksimal 24 kali dalam sekali eksekusi. Ukuran cambuk 
dengan panjang 1,2 meter dan tebal 1,27 cm. Dalam pelaksanaannya, terpidana hukum cambuk akan diminta untuk telanjang, kemudian dokter akan memeriksa kondisi medisnya sebelum eksekusi dilakukan. Jika kondisi fisiknya layak, eksekusi pun dilaksanakan. Untuk mereka yang kondisinya tidak memungkinkan untuk menerima hukuman cambuk, maka hukuman akan dialokasikan kepada hukuman penjara (Tenawin, 2015).

Proses dalam pelaksanaan hukuman cambuk dimana terpidana akan dicambuk di bagian pantatnya dengan sekuat tenaga oleh sipir penjara dengan jeda 15 detik antara 1 cambukan kecambukan berikutnya. Sampai seluruh jumlah cambukan yang harus ditanggung telah dipenuhi atau sampai petugas medis menyatakan kondisi yang bersangkutan sudah tidak sanggup menerima cambukan. Akibat yang ditimbulkan dari cambukan ini bisa beragam tergantung banyaknya cambukan yang harus ditanggung. Dari memar hingga mengeluarkan darah. Setiap selesai menerima cambukan, petugas medis akan langsung mengobati dan memberikan lotion antiseptik pada luka bekas cambukan. Proses penyembuhan luka akan berlangsung antara dua minggu sampai satubulan. Luka ini umumnya akan meninggalkan bekas yang sulit hilang (Tenawin, 2015).

Bila dibandingkan hukuman cambuk yang dilakukan di Singapura dengan yang diadakan di Aceh sedikit berbeda. Hukuman cambuk yang dilaksanakan di Aceh tidak memandang jenis kelamin. Beda dengan pelaksanaan hukuman cambuk di Sigapura yang hanya berlaku untuk laki-laki yang berumur 18 sampai 50 tahun. Namun lokasi pelaksanaannya juga berbeda. Di singapura pelaksanaanya hukuman ini diadakan di penjara sedangkan di Aceh pelaksanaan hukuman cambuk dilaksanakan di lapangan di depan masjid dan dapat disaksikan oleh masyarakat.

Dari segi banyaknya hukuman cambuk yang akan diterima terdakwa pelecehan seksual, hukuman cambuk di Singapura dan di Aceh berbeda. Qanun Jinayat yang mengatur soal pidana pelecehan seksual. Pasal 46 Qanun mengancam dengan hukuman 45 kali cambuk atau denda paling banyak 450 gram emas murni atau penjara paling lama 45 bulan (Gade, 2015). Sedangkan terdakwa untuk pelanggaran seksual hanya dihukum 24 kali cambukan.

Sebagai contoh hukuman cambuk yang menjadi fenomenal adalah hukuman cambuk pada Kasus pelanggaran syari'ah yang dilakukan oleh pasangan Gay yang berakhir dengan hukuman cambuk pada tanggal 23 mei 2017 lalu menjadi isu hangat yang diangkat oleh berbagai media baik media lokal maupun media asing. Ada dua isu yang menjadi focus dalam kasus ini yaitu isu hukum cambuk dan pasangan gay. Pasangan gay yang diadili oleh Mahkamah Syari'ah tersebut dikenakan Pasal 63 ayat 1 Qanun Nomor 6 Tahun 2014 tentang Hukum Jinayat yang berbunyi "Setiap orang yang dengan sengaja melakukan Jarimah Liwath diancam dengan 'Uqubat Ta'zirpaling banyak 100 (seratus) kali cambuk atau denda paling banyak 1.000 (seribu) gram emas murni atau penjara paling lama 100 (seratus) bulan." Pasal tersebut menjelaskan bahwa hukuman yang terima adalah 100 kali cambuk. Akan tetapi pasangan gay yang melakukan tindakan asusila tersebut hanya didera hukuman 85 kali cambukan (Juliani, 2017: 455).

Qanun Jinayat sendiri baru disahkan pada tahun 2014. Qanun Jinayat No. 6 Tahun 2014 tentang Hukum Jinayat ini mulai berlaku pada Tanggal 23 Oktober 2015, setahun setelah disahkannya. Hukum Jinayat ini merupakan hukum pidana yang memuat ketetuan hukuman cambuk dan rajam. Juga menegaskan pada tindakan yang melanggar Syari'at seperti zina, maisir, dan banyak lagi termasuk liwath (homoseksual). Dalam Qanun Jinayat No.6 tahun 2014 Pasal 63 menyebutkan perihal liwath yang berbunyi sebagai berikut:

1. Setiap Orang yang dengan sengaja melakukan Jarimah Liwath diancam dengan 'Uqubat Ta'zir paling banyak 100 (seratus) kali cambuk atau denda paling banyak 1.000 (seribu) gram emas murni atau penjara paling lama 100 (seratus) bulan.

2. Setiap Orang yang mengulangi perbuatan sebagaimana dimaksud pada ayat (1) diancam dengan 'Uqubat Ta'zir cambuk 100 (seratus) kali dan dapat ditambah dengan denda paling banyak 120 (seratus dua puluh) gram emas murni dan/atau 
penjara paling lama 12 (dua belas) bulan

3. Setiap Orang yang melakukan Liwath dengan anak, selain diancam dengan 'Uqubat Ta'zir sebagaimana dimaksud pada ayat (1) dapat ditambah dengan cambuk paling banyak 100 (seratus) kali atau denda paling banyak 1.000 (seribu) gram emas murni atau penjara paling lama 100 (seratus) bulan (Juliani, 2017: 459).

Pelaksanaan hukum cambuk bagi kaum gay dan lesbian di negara lain akan lebih parah pelaksanaannya. Menurut washington Post (Wicaksono dan Alia, 2016) bahwa ada 10 negara yang memberlakukan hukuman mati untuk pasangan sejenis, baik pasangan sejenis pria maupun pasangan sejenis wanita. Data yang mereka miliki, kebanyakan negara Islam yang memberlakukan hukuman tersebut. Pelaksanaan hukuman mati pun cukuo mengerikan, ada yang dilempari batu sampai mati dan dicambuk sampai mati. 10 negera tersebut antara lain (Wicaksono dan Alia, 2016):

1. Yaman

Di negara ini ada hukum pidana yang diberlakukan sejak 1994. Dalam hukum itu, seorang pria yang sudah menikah akan dilempar batu sampai meninggal jika ternyata gay. Sedangkan pria yang belum menikah akan dicambuk di bagian wajah atau dipenjara selama satu tahun. Lain halnya dengan wanita lesbian yang diancam hukuman tujuh tahun penjara.

2. Iran

Iran menganut hukum syariah. Pria yang ketahuan sebagai gay akan dihukum mati atau dihukum cambuk jika ketahuan berciuman. Sama halnya dengan lesbian yang juga akan dihukum cambuk.

3. Irak

Hukum pidana di Irak tidak secara langsung menyebut hukuman bagi pasangan homoseksual. Namun dari kejadian yang ada, pasangan gay akan dibunuh oleh militer dan dihukum sampai mati oleh hakim, merujuk pada hukum syariah.

4. Mauritania

Seorang pria muslim yang menjadi gay akan dihukum lempar batu sampai mati. Ini tertuang dalam hukum yang ditegaskan sejak 1984. Sedangkan wanita lesbi akan diancam hukuman penjara.

5. Nigeria

Hukum federal di negara ini mengkelompokkan gay sebagai perilaku kejahatan yang dapat dihukum penjara. Namun beberapa wilayah di negara itu telah mengadopsi hukum syariah dan memberlakukan hukuman mati bagi gay. Bahkan sebuah aturan baru saja diberlakukan pada Januari yang melarang gay untuk mengadakan pertemuan atau membentuk forum.

6. Qatar

Hukum syariah telah diberlakukan di negara ini, namun hanya untuk pria muslim yang ketahuan sebagai gay. Mereka bisa dihukum mati jika ketahuan memiliki orientasi seksual berbeda.

\section{Arab Saudi}

Hukum syariah sangat ditegaskan di negara ini. Semua perilaku seksual yang menyimpang akan dihukum mati melalui lempar batu tanpa henti. Sodomi, gay, atau berhubungan di luar nikah dianggap sebagai kejahatan.

8. Somalia

Hukum pidana akan diberlakukan bagi gay dengan ancaman penjara. Namun di beberapa wilayah, khususnya di selatan, sudah diberlakukan hukum syariah dengan ancaman mati.

9. Sudan

Kasus sodomi akan menghadapi hukum cambuk dan penjara di negara ini. Namun 
jika terjadi sampai tiga kali dan tersangka tidak juga insaf maka hukuman mati akan menanti.

10. Uni Emirat Arab

Perangkat hukum di negara ini tidak setuju jika hukum federal disebut sebagai dasar pemberlakukan hukuman mati bagi homoseksual, atau hanya untuk pemerkosa. Namun yang jelas, semua kasus seksualitas di luar nikah dilarang keras.

\section{Pemindahan Lokasi Pelaksanaan Hukum Cambuk}

Gubernur Aceh, Irwandi Yusuf, mengatakan alasan pemindahan lokasi pelaksanaan hukuman cambuk ke dalam lembaga pemasyarakatan ditempuh agar investasi di Provinsi Aceh tidak terganggu. Irwandi menyebutkan juga alasan pemindahan lokasi pelaksanaan hukuman tersebut agar investor tidak fobia untuk menanam saham di Aceh. Ini juga dapat membantu peningkatan dan lajur ekonomi di Aceh. Selain itu, pelaksanaan cambuk yang dilakukan di dalam lapas dilakukan untuk menghindari beredarnya video wajah terpidana di media sosial seperti Youtube. Dengan beredarnya video, seumur hidup dia akan menjadi terpidana. Alasan Irwandi tersebut berbeda dengan Fuad Mardhatillah. Menurut pengamat hukum Universitas Islam Negeri Ar-Raniry ini, ada kesalahan dalam penerapan syariat Islam yang selama ini dilaksanakan di Provinsi Aceh. Dia menilai seharusnya cambuk itu menjadi introspeksi diri bukan untuk mempermalukan."Cambuk yang dilakukan hari ini semacam euforia. Jadi ketika ada orang yang dicambuk para penonton bersorak ria, bertepuk tangan dan mengabadikan dengan telepon seluler," kata Fuad. Akan tetapi, dia berpandangan pemindahahan lokasi cambuk ke dalam lapas tidak ada sangkut paut dengan investasi di Aceh selama ini. Masalah investasi tidak ada hubungannya, saya rasa cambuk ini hanya masalah politik partai tertentu saja," (Hidayatullah, 2018).

Pada media tribunnews.com edisi Kamis 12 April 2018, Irwandi menjelaskan alasannya memindahkan lokasi pelaksanaan hukuman cambuk ke penjara. Salah satu alasan terbesar keputusan Irwandi adalah gelombang kritik dari masyarakat internasional setiap kali hukuman cambuk diterapkan di Aceh. Terakhir Aceh mendulang hujan kecaman setelah menghukum cambuk dua pasangan gay dan mengusulkan pemberlakuan hukuman pancung untuk pelaku pembunuhan. Menurut Irwandi keputusannya bertujuan untuk meredam protes pihak luar, beliau juga tidak ingin hasil rekaman hukuman cambuk di Aceh memperkuat Islamofobia di luar negeri. Meski begitu ia masih mengizinkan masyarakat dan wartawan untuk menyimak proses eksekusi langsung. 


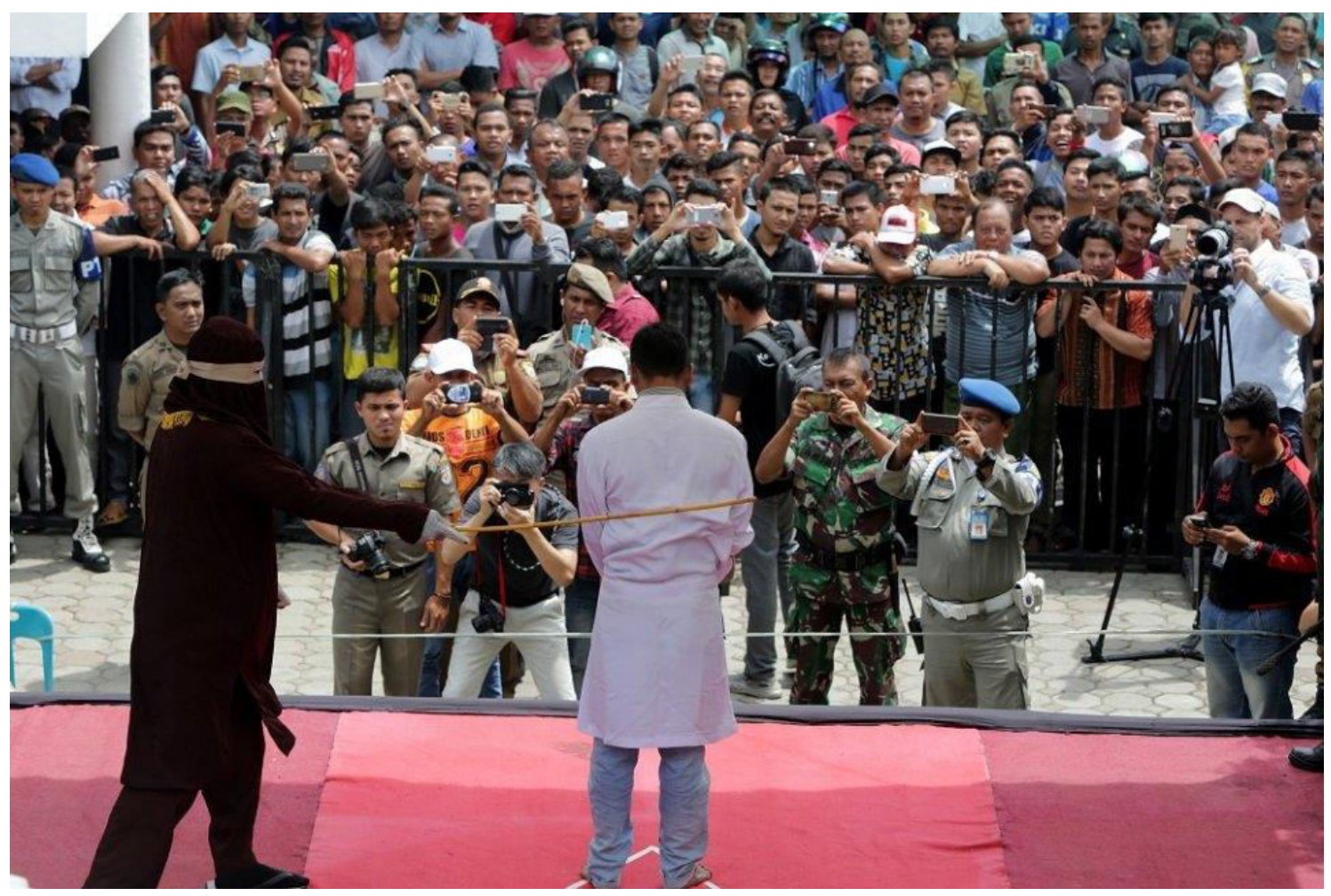

(Sumber: Putra, 2017)

\section{Teori Spiral of Silence}

Teori spiral kesunyian itu sendiri semula dibuat oleh Noelle-Neumann untuk menjelaskan fenomena pembentukan opini publik pada Pemilu di Jerman Barat tahun 1965 dan 1972. Sejak tahun 1980an telah banyak studi mengenai teori spiral kesunyian yang dilakukan di sejumlah negara yang mempunyai karakteristik media, sistem politik dan pemerintahan dan budaya yang berbeda dengan Jerman. Studi-studi tersebut memperlihatkan bahwa teori spiral kesunyian bisa dipakai menjelaskan proses pembentukan opini publik dalam konteks negara yang berbeda. Meski demikian, ada celah (gap) yang belum terjawab dari sejumlah studi mengenai teori spiral kesunyian. Yakni, apakah teori spiral kesunyian (dan teori pembentukan opini publik lainnya) bisa dipakai untuk menjelaskan terbentuknya opini publik di negara dengan pendidikan warganya yang masih rendah dan akses terhadap media yang relatif masih kecil. Teori pembentukan opini publik didasarkan pada asumsi bahwa masyarakat sadar (aware) dengan isuisu publik, selalu mengawasi opini yang berkembang dalam masyarakat. Individu digambarkan mempunyai kemampuan dalam melihat opini apa yang ada dalam masyarakat dan menentukan opini pribadinya di tengah opini yang berkembang dalam masyarakat (Eriyanto, 2012:14).

Pengertian opini publik adalah sikap seseorang mengenai suatu hal, dimana mereka merupakan anggota sebuah masyarakat yang sama, sehingga opini publik berhubungan dengan sikap manusia, baik sikap secara pribadi maupun sikap manusia secara kelompok. Sikap manusia itu sendiri ditentukan berdasarkan atas pengalaman yang terjadi pada manusia atau kelompok tersebut. Opini publik tersebut akan menguat apabila dibarengi dengan beberapa opini kelompok sehingga opini publik dapat bergerak. Akar dari opini sebenarnya tak lain adalah persepsi, yang ditentukan oleh faktor seperti : (1) latar belakang budaya, (2) pengalaman masa lalu, (3) nilai-nilai yang dianut, dan (4) berita-berita yang berkembang (Mellisa, 2013 :344-345). 


\section{HASIL DAN PEMBAHASAN}

Penelitian ini bertujuan untuk menganalisis bagaimana mahasiswa Prodi Ilmu Hukum FISIP UTU menanggapi perihal isu pemindahan lokasi pelaksanaan hukum cambuk ke penjara, oleh sebab itu peneliti menyebarkan 20 kuisioner untuk 20 mahasiswa untuk mendiskripsikan pendapat mereka yang berasal dari beberapa pertanyaan tertutup.

Tabel 1. Pertanyaan Penelitian 1

\begin{tabular}{|c|c|c|}
\hline \multicolumn{3}{|c|}{ Apakah anda setuju apabila hukum cambuk tidak diadakan lagi } \\
di masjid namun di penjara?
\end{tabular}

Tabel di atas menunjukkan bahwa ada 13 orang mahasiswa Prodi Ilmu Hukum FISIP UTU yang menyatakan tidak setuju apabila pelaksanaan hukum cambuk dilakukan di penjara. Sebagian mereka memilih setuju, yaitu sebanyak 6 orang dan hanya 1 orang yang menyatakan netral terhadap pendapat pemindahan lokasi pelaksanaan hukum cambuk. Hal tersebut dapat disimpulkan bahwa dominan mahasiswa Prodi Hukum FISIP UTU tidak setuju apabila hukum cambuk tidak diadakan lagi di masjid namun di penjara.

Tabel 2. Pertanyaan Penelitian 2

\begin{tabular}{|c|c|c|}
\hline \multicolumn{3}{|c|}{ Apakah menurut anda hukum cambuk yang diadakan di penjara } \\
akan membuat jera?
\end{tabular}

Dapat kita lihat dari tabel di atas bahwa kebanyak mahasiswa Prodi Ilmu Hukum FISIP UTU menyatakan tidak setuju. Hal ini diartikan hukuman cambuk yang diadakan di penjara tidak akan membuat terdakwa jera dengan kesalahan yang telah dilakukannya. Ada 3 orang yang menyatakan netral dan ada 4 orang yang menyatakan setuju dengan pertanyaan di atas. Dengan demikian dapat disimpulkan bahwa mahasiswa Prodi Hukum FISIP UTU merasa apabila pelaksanaan hukum cambuk dipindahkan ke penjara, maka efek jera terhadap perbuatan yang dilakukan terdakwa tidak ada.

Tabel 3. Pertanyaan Penelitian 3

\begin{tabular}{|c|c|c|}
\hline $\begin{array}{c}\text { Apakah menurut anda dengan diadakannya pelaksanaan hukum } \\
\text { cambuk di masjid akan membuat investor merasa fobia untuk } \\
\text { menanamkan sahamnya di Aceh? }\end{array}$ \\
\hline Tidak Setuju & Netral & Setuju \\
\hline 8 & 6 & 6 \\
\hline
\end{tabular}

Tabel di atas menunjukkan bahwa perbandingan jumlah pendapat mahasiswa Prodi Ilmu Hukum FISIP UTU yang menyatakan setuju dan tidak setuju juga yang menyatakan netral, jumlahnya hampir sama. Namun pendapat dominan dari mahasiswa Prodi Ilmu Hukum FISIP UTU yaitu mereka menyatakan tidak setuju apabila pelaksanaan hukum cambuk di masjid akan membuat investor merasa fobia untuk menanamkan sahamnya di Aceh. 
Tabel 4. Pertanyaan Penelitian 4

\begin{tabular}{|c|c|c|}
\hline \multicolumn{3}{|c|}{$\begin{array}{l}\text { Apakah anda setuju alasan diadakan hukum cambuk di penjara } \\
\text { agar tidak ada lagi rekaman video pelaksanaan hukum cambuk } \\
\text { yang dianggap akan menjadikan terpidana menjadi terpidana } \\
\text { seumur hidup? }\end{array}$} \\
\hline Tidak Setuju & Netral & Setuju \\
\hline 14 & 2 & 4 \\
\hline
\end{tabular}

Dari tabel di atas kita bisa melihat perbedaan yang signifikan dari pernyataan pendapat mahasiswa Prodi Hukum Ilmu FISIP UTU bahwa ada 14 orang atau lebih dari setengah dari julah mahasiswa yang diberikan kuisioner menyatakan tidak setuju bahwa apabila hukum cambuk yang ada akan diadakan di penjara akan menghindari hadrinya rekaman video pelaksanaan hukum cambuk tersebut yang nantinya akan beredar di berbagai media, dan bisa disaksikan oleh siapa saja termasuk terdakwa sendiri. Mereka menganggap hal ini tidak akan membuat terdakwa menjadi terdakwa seumur hidup. Namun ada 2 orang yang menyatakan netral dan ada 4 orang yang menyatakan setuju dengan hal tersebut.

Tabel 5. Pertanyaan Penelitian 5

\begin{tabular}{|c|c|c|}
\hline \multicolumn{3}{|c|}{$\begin{array}{c}\text { Apakah menurut anda pelaksanaan hukum cambuk di masjid } \\
\text { merupakan bentuk pelanggaran HAM? }\end{array}$} \\
\hline Tidak Setuju & Netral & Setuju \\
\hline 19 & 1 & 0 \\
\hline
\end{tabular}

Dilihat dari hasil penelitian yang dipaparkan dalam tabel di atas dapat kita simpulkan bahwa hampir semua informan yang teliti menyatakan tidak setuju apabila pelaksanaan hukum cambuk di masjid dianggap satu bentuk pelanggaran HAM. Jadi bisa kita ambil kesimpulan bahwa dominan mahasiswa Prodi Ilmu Hukum FISIP UTU menyatakan tidak setuju apabila pelaksanaan hukum cambuk di masjid disebut bentuk pelanggaran HAM.

Tabel 6. Pertanyaan Penelitian 6

\begin{tabular}{|c|c|c|}
\hline \multicolumn{3}{|c|}{$\begin{array}{c}\text { Apakah menurut anda pemindahan pelaksanaan hukum cambuk } \\
\text { ke penjara ada kaitannya dengan kepentingan politik? }\end{array}$} \\
\hline Tidak Setuju & Netral & Setuju \\
\hline 8 & 1 & 11 \\
\hline
\end{tabular}

Seperti yang terlihat dari tabel, bahwa ada 8 mahasiswa Prodi Ilmu Hukum FISIP UTU yang menyatakan tidak setuju apabila pemindahan pelaksanaan hukum cambuk ke penjara ini dituding terkait dengan kepentingan politik. Namun ada 11 mahasiswa yang menyatakan setuju dan ada 1 orang yang menyatakan netral. Hal tersebut menyatakan bahwa mahasiswa Prodi Ilmu Hukum FISIP UTU menganggap adanya kepentingan politik yang melatarbelakangi pemindahan lokasi pelaksanaan hukum cambuk ke penjara.

Tabel 7. Pertanyaan Penelitian 7

\begin{tabular}{|c|c|c|}
\hline \multicolumn{3}{|c|}{$\begin{array}{c}\text { Apakah menurut anda akan ada penyelewengan pelaksanaan } \\
\text { hukum cambuk bila dipindahkan ke penjara semisal yang } \\
\text { berkuasa dan kaya tidak akan dikenakan cambuk? }\end{array}$} \\
\hline Tidak Setuju & Netral & Setuju \\
\hline 4 & 3 & 13 \\
\hline
\end{tabular}


Dari tabel di atas dapat kita lihat dominasi mahasiswa Prodi Ilmu Hukum FISIP UTU yang berjumlah 13 orang menyatakan setuju dengan pertanyaan di atas sedangkan ada 4 orang yang menyatakan tidak setuju dan ada 1 orang yang menyatakan netral. Hal ini dapat disimpulkan bahwa mahasiswa Prodi Ilmu Hukum FISIP UTU menyatakan akan ada penyelewengan pelaksaan hukum cambuk apabila dipindahkan ke penjara. Hukum cambuk tersebut ditakutkan hanya akan berlaku untuk terdakwa yang berasal dari kalangan bawah dan tidak mempunyai kekuasaan.

\section{PENUTUP}

Dari apa yang telah dijelaskan maka dapat disimpulkan bahwa mahasiswa Prodi Ilmu Hukum FISIP UTU tidak setuju dengan rencana pemerintah untuk memindahkan lokasi pelaksanaan hukum cambuk ke penjara. Hal ini dianggap bahwa hukuman tersebut tidak akan membuat terdakwa jera karena efek malu tidak ada. Terdakwa tidak akan dihukum oleh masyarakat karena tidak dipertontonkan di depan umum. Selain itu adanya pelarangan untuk mengambil gambar dan rekaman ketika proses pelaksanaan hukum cambuk tersebut, mahasiswa Prodi Ilmu Hukum Fisip UTU menilai hal itu tidak perlu dilarang. Selain itu mereka menganggap pelaksanaan hukum cambuk di masjid tidak akan menimbulkan rasa fobia investor untuk menanamkan sahamnya ke Aceh dan pelaksanaan hukum cambuk di masjid tidak melanggar hak-hak asasi manusia. Mahasiswa Prodi Ilmu Hukum FISIP UTU juga menuding perpindahan lokasi pelaksanaan hukum cambuk ini sarat dengan kepentingan politik sehingga nantinya ditakutkan pihak yang berkuasa yang melakukan pelanggaran syariah tidak akan menerima hukuman cambuk karena kekuasaan yang dimilikinya.

Setelah melakukan penelitian mengenai bagaimana mahasiswa Prodi Ilmu Hukum FISIP UTU menanggapi perihal isu pemindahan lokasi pelaksanaan hukum cambuk ke penjara, maka penulis memberikan beberapa saran antara lain:

1. Penulis mengharapkan pemerintah apabila terealisasinya pemindahan pelaksanaan hukum cambuk tersebut, maka harap berlaku adil. Karena hukum tidak runcing ke bawah, namun hukum berlaku untuk seluruh masyarakat.

2. Penulis mengharapkan apabila memang ingin Syari'at ini dijalankan secara kaffah, maka ada baiknya pemerintah meneliti bagaimana Perjanjian Madinah yang telah disepakati Internasional itu dibuat sehingga Pemerintah Provinsi Aceh bisa mencontoh langkah-langkah yang dilakukan Pemerintah Madinah.

3. Penulis mengharapkan kepada mahasiswa sebagai agent of change untuk terus memantau kebijakan yang diambil pemerintah agar nantinya kebijakan tersebut tidak merugikan masyarakat.

\section{REFERENSI}

.Bantasyam, Saifuddin dan Siddiq, Muhammad (ed). (2009). Aceh Madani dalam Wacana: Format Ideal Implementasi Syari'at Islam di Aceh. Banda Aceh: Aceh Justice Resource Center (AJRC).

Eriyanto. 2012. Teori Spiral Kesunyian dan Negara Transisi Demokrasi: Sebuah Pengujian di Indonesia. Jurnal Komunikasi Indonesia. Vol I (1): 13-22.

Gade, Fakhrurradzie. 2015. Qanun Jinayat. http://www.acehkita.com/ini-besaranhukuman-cambuk-dalam-qanun-jinayat/. Diakses Pada Tanggal 17 April 2018.

Hidayatullah. 2018. Alasan Investasi, Hukuman Cambuk di Aceh Dipindah ke dalam LP. http://www.bbc.com/indonesia/indonesia-43739493. Diakses Pada Tanggal 17 April 
2018.

http://www.tribunnews.com/internasional/2018/04/12/banjir-kritik-aceh-pindahkan-eksekusihukuman-cambuk-ke-penjara

Juliani, Reni. 2017. Media Asing dan Perda Aceh: Pro Kontra Pemberitaan Hukum Cambuk Gay di Aceh. E-Proceeding COMICOS Developing Knowledge Community Quintuple Helix and Beyond.

Mellisa. 2013. Pembentukan Opini Publik Tentang Citra Polisi Terkait Berita Tindak Kekerasan Polisi di Harian Samarinda POS Studi Deskriptif Pada Masyarakat Kelurahan Bandara Samarinda. Ejournal Ilmu Komunikasi. Vol I (2):236-248.

Putra, Irwansyah. 2017. Demi Investasi Aceh, Jokowi Minta Hukuman Cambuk Digelar Tertutup. https://katadata.co.id/berita/2017/07/11/demi-investasi-aceh-jokowi-mintahukuman-cambuk-digelar-tertutup. Diakses Pada Tanggal 17 April 2018.

Surry, Khalis. 2018. Hukuman Cambuk di Aceh Kini Dilakukan di Penjara, Bukan di Depan Umum Lagi. https://news.okezone.com/read/2018/04/12/340/1885760/hukumancambuk-di-aceh-kini-dilakukan-di-penjara-bukan-di-depan-umum-lagi. Diakses Pada Tanggal 17 April 2018.

Tenawin, 2015. Merlion Chapter One : Hukuman Cambuk di Singapura. http://www.kompasiana.com/deirdretenawin/merlion-chapter-one-hukuman-cambuk-disingapura_55d8095b779373f71bddae82. Diakses Pada Tanggal 10 Juli 2017.

Wicaksono, Bayu Adi dan Alia, Siti Sarifah. (2016). 10 Negara yang Berlakukan Hukum Mati Mengerikan Bagi LGBT. http://m.viva.co.id/amp/berita/dunia/784733-10-negara-yangberlakukan-hukum-mati-mengerikan-bagi-lgbt/2.Diakses Tanggal 03 Juli 2017.

Yani, Muhammad. (2011). Pelaksanaan Hukum Jinayat di Aceh dalam Perspektif Hukum dan HAM: Studi Qanun Nomor 12, 13, dan 14 Tahun 2003. Banten: Isdar Press 